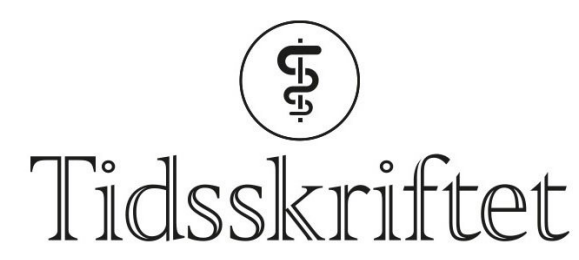

DEN NORSKE LEGEFORENING

\title{
Problem eller utfordring?
}

SPRÅKSPALTEN

\section{TRUDE FIXDAL}

E-post: trudecharlotte.fixdal@lds.no

Trude Fixdal (f. 1964) er spesialist i psykiatri og i barne- og ungdomspsykiatri og overlege ved Nic Waals Institutt.

Jeg blir provosert når politikere omtaler en alvorlig psykisk lidelse som en utfordring. Det er forskjell på utfordring og problem.

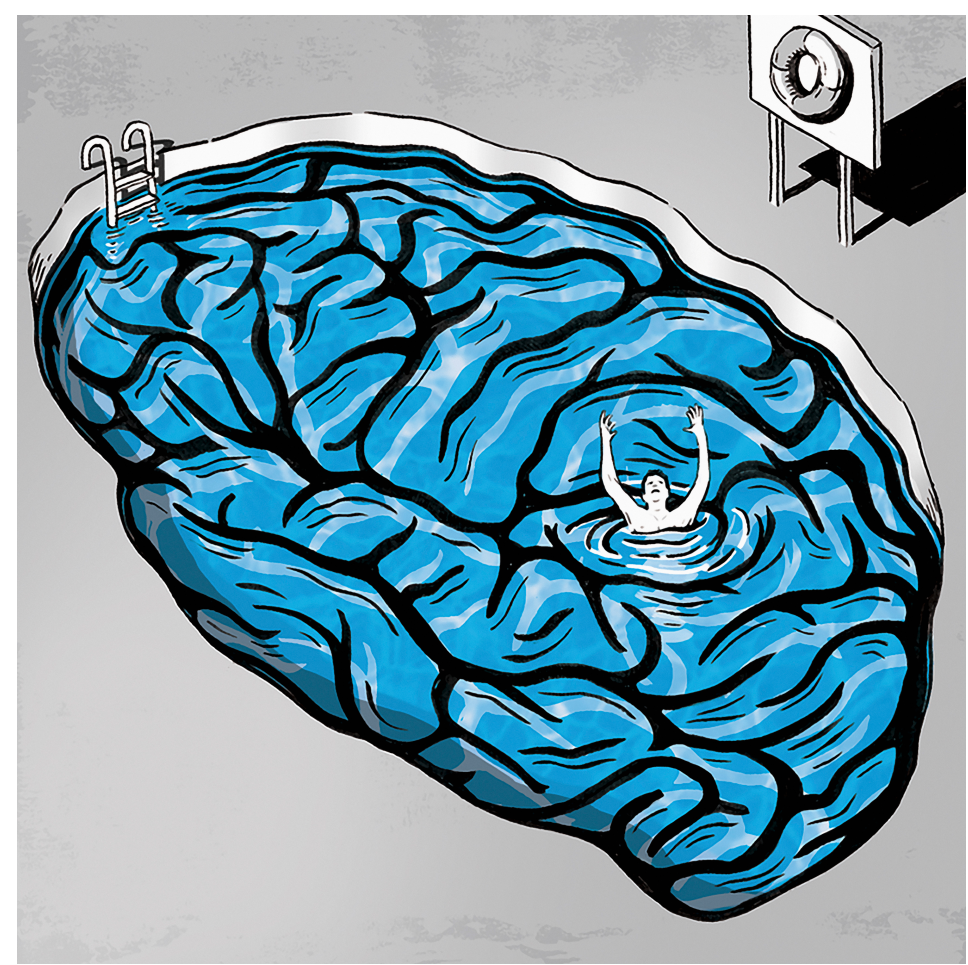

Illustrasjon: NTB scanpix/Dan Mitchell

Ordet «utfordring» beskriver noe man kan strekke seg etter, en situasjon der man får brukt sine ferdigheter og evner og kan presse grensene for hva man egentlig klarer. Det er noe det kan være mulig å oppnå. Eksempler er å klatre opp på et høyt fjell, lære seg italiensk, gå Birkebeineren på under tre timer, lage en syvretters middag til 15 personer og så videre. Det er forbundet med noe positivt. Selv om det kan være slitsomt og vanskelig, gir det en opplevelse av mestring. Det er ikke så farlig om man ikke klarer det, for det går fint an å bruke lengre tid på Birken.

Et problem er noe mer alvorlig. Det er noe som man ikke nødvendigvis kan løse ved å strekke seg litt lenger. Det er mer omfattende, og man kan trenge hjelp for å finne en 
løsning. Å være alvorlig psykisk syk er et problem. Det rammer alle sider av livet og gjør at livskvaliteten blir dårligere. Det er ikke sikkert at man finner en klar løsning på problemet. Kanskje er det et problem man kommer til å ha store deler av livet?

Jeg mener at å beskrive alvorlig psykisk lidelse som en utfordring - eller psykiske helseutfordringer, som helseminister Bent Høie sier - er å kamuflere hvor alvorlig en slik tilstand kan være. I mediearkivet Retriever gir uttrykket "psykiske helseutfordringer» over 1 ooo treff. Det ble registrert første gang i 2008, men var nesten ikke i bruk før det fikk et kraftig oppsving i valgkampen i 2013.

Når man beskriver noe som en utfordring, ligger det en forventning om at hvis man bare tar seg sammen og presser seg litt eller strekker seg litt lenger, så får man det til. Det er som å si til folk med psykiske lidelser at hvis de gjør det, går det bedre. Ordet utfordring legger i større grad ansvaret for løsningen på den enkelte, i stedet for at man skal jobbe sammen for å finne en løsning på et problem. Det er ille nok og ensomt nok å ha en psykisk lidelse - om man ikke også skal få ansvaret for å bli kvitt den. Og hva hvis man ikke klarer det? Ville man brukt samme begrep om mennesker som får kreft - at de har en «kreftutfordring»?

Jeg er klar over at ordet utfordring har fătt utvidet betydning i de senere år, slik at det nå i en del sammenhenger brukes synonymt med problem. Helt overlappende er de likevel ikke. Ordet utfordring sprer seg som brunsneglen i norsk offentlighet og dukker opp på stadig nye arenaer (1). Vi har ikke problemer her i landet lenger - bare utfordringer. Vi har rett og slett døpt problem om til utfordring (2). Spesielt ille blir det når man lager ordkombinasjoner som utfordringsbilde eller krevende utfordring!

Det er et demokratisk problem at man har sluttet å bruke ordet problem om det som er et problem (1-4). Utfordringen er gitt: Kall en spade for en spade! Gi oss problemene våre tilbake slik at vi kan få gjort noe med dem!

\section{LITTERATUR:}

1. Kolshus T. Det problemfrie samfunn. Aftenposten 3.5.2013. www.aftenposten.no/meninger/kommentar/i/3JJrA/Det-problemfrie-samfunn (10.12.2017).

2. Tangerud PM. Ord og utfordringer. Drammens Tidende 15.12.2014: 11.

3. Hegge PE. Utfordringsveien. Aftenposten 5.1.2014. http://tux.aftenposten.no/spraak/spraak?actionquestion\&id=5251 (10.12.2017).

4. Markussen MÅ. - Hva er galt med ordet "problem»? Forskning.no 17.4.2015. https://forskning.no/2015/o4/hva-er-galt-med-ordet-problem (10.12.2017).

Publisert: 28. mai 2018. Tidsskr Nor Legeforen. DOI: 10.4045/tidsskr.18.0150

(C) Tidsskrift for Den norske legeforening 2020. Lastet ned fra tidsskriftet.no 